\title{
Museums as Our New Epic Theatre
}

\section{Mariko Izumi}

Columbus State University

Columbus, GA

Poroi 10,2 (December 2014)

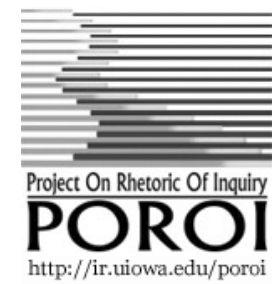

Man's view is always reduced to man's mind.

For this is the part of himself he values most. THE MIND. The intellect and its powers. Storytelling allows the 'civilized' narrator above all to renew his mind and exercise power through his intellect. Even through the motto reads 'Think, act, and feel,' his task, he believes, is to ease the passage of the story from mind to mind.

$$
\text { -Trinh T. Minh-ha }
$$

What is the role of museums in shaping and reshaping the public sphere? Committed to the centrality of rhetoric in deliberative democracy, Alan Gross has extended his work to the studies of museum exhibits. In particular, his work on exhibits involving wartime atrocities foregrounds a notion of learning that is often tacitly articulated in the acts of remembrance. As Toby Miller and George Yudice write, "Historical citizenship emerges in the contemporary moment, but in reaction to the past. [...] The past's commemoration in museum form is rendered as a strictly delimited ethical zone, a space that divides worthy and unworthy conduct." (Miller and Yudice, 2002, 148). The pedagogical role of the modern museum sites thus raises questions concerning its moral dimension in relation to civic virtue and responsible citizenship. ${ }^{1}$ In what ways can museum exhibits animate discourses, make political and cultural norms visible, and problematize the ways in which we conduct our lives? Are museums to be construed as venues for "consciousness raising," to borrow Habermas's phrase, so that we will not repeat history? And if so, does that entail vesting museum exhibits with a more or less explicit moral agenda, framed by a vision of social progress? Differently put, if one assumes that museums have a critical role to play in the shaping of public memory, what is the underlying critique on which this assumption

${ }^{1}$ Toby Bennett traces the emergence of museums as aimed at the pedagogy of citizenship. See Bennett, 1995, especially 25-33. 
is based, and is such a critical role best understood in moral, or moralistic, terms? It is in the context of these questions that the work of Alan Gross assumes its significance and urgency for a contemporary readership concerned with the meaning-sponsoring powers of museums and the ways in which they negotiate temporal and moral aspects of civic self-understanding.

What makes Gross's writings instructive is that they provide us with a theoretical idiom whose critical terms invite us to re-imagine the societal significance of museums in the $21^{\text {st }}$ century. At the same time, this call for a new vision of museums as sites for civic selfreflection is not free of internal tension. In the following, I wish to explicate how destabilization plays an important yet ambivalent role in Gross's critique of historical exhibits. Next, I discuss how this notion is at odds with his conception of museum exhibit as a form of public address, and then elaborate on the idea of museum as new "epic theatre" by using a recently opened exhibit at the United States Holocaust Memorial Museums for illustration.

\section{Against Monumentalization of Public Memory}

Gross's work on historical exhibits invites us to think of museums as double gateways which open new futures (new social visions) for us by facilitating engagement with our (im/moral) past. He writes, "We can see them [historical museum visits] as activities that encourage a reflective confrontation with existing knowledge and values. [...] The museum experience enacts a democratic philosophy of public education, one in which a reflective confrontation with a nation's past can affect public policy" (Gross, 2002, 476). Gross considers the Enola Gay exhibit planned by the Smithsonian Institute a missed opportunity to "locat[e] the struggle for the meaning of Hiroshima where it belonged [...] within the consciousness and conscience of every American" (Gross, 2002, 484). He believes in creating the "presence" of the historical past in our contemporary lives so as to keep contemporary public life open for change. Drawing on Pierre Nora, his treatment of Hiroshima as "American "lieux de memoire" and the Holocaust as "an unmasterable past" shows how his understanding of public memory as something in constant flux, without stabilization (Gross, 2002, 467; Gross, 2006, 310). It is, to continue borrowing Nora's account, "an endless recycling of meaning", which does not end with "true" memory (Nora, 1989, 8).

For this reason, Gross also criticizes the Vienna 1938 exhibit in Austria, as a failure to generate public debate over "minimizing the Holocaust as a living presence in Austrian life" (Gross, 2005, 7). From Gross's perspective, such failure is a missed opportunity to 
"achieve the true balance between remembering and forgetting [...] [and] confidently create a viable democratic future out of a barbaric and totalitarian past" (Gross, 2005, 311.) Through these critiques, it becomes clear that Gross is opposed to monumentalizing historical events, i.e., he sees the closure of public discourse as tantamount to a spurious stabilization of public memory. As James Young writes, "The traditional aim of war monuments has been to valorize the suffering in such a way as to justify, even redeem, it historically," and "once we assign monumental form to memory, we have to some degree divested ourselves of the obligation to remember" (Young, 2000, 95, 94).

For Gross, then, museums should be provocative, promoting public debates and "serious citizen reflection" (Gross, 2002, 476). Drawing on the legacy of John Dewey, he expands on the Smithsonian Institute's failure to effectively open the Enola Gay exhibit to the public, as follows:

The democratic hope lies, not in the suppression of either of these [competing] views [on atomic bombs], but in the creation of public spaces hospitable to both and, equally, to their critique: such public spaces will, in Mark Osiel's words, create 'public memory publicly' (Gross, 2002, 484).

By insisting on public participation in the making of history and memory, his main objective is neither reconciliation nor resolution of competing views. In other words, he is not advocating stability by way of settling historical viewpoints and interpretations. Rather, he focuses on destabilizing our moral perceptions resulting from the encounter with a particular museum exhibit. Over and against the typical misconception that museums are in the business of presenting fixed and stable sets of data, Gross considers museums as a site of "selective narrativization" that ought to challenge the common conception that, "like a play, the war is over; its consequences can haunt only the neurotic" (Gross, 2002, 470, 473).

However, this notion of "reflective confrontation," which lies at the heart of Gross's account, is not altogether clear. Specifically, Gross's overall proposal to envision museum sites as catalysts for moral education does not immediately reveal just how open-ended this process of challenging the individual and social structure of moral perceptions is supposed to be. When Gross speaks of the Vienna 1938 exhibit as a "missed opportunity" for generating public discussions and confronting the nation's complicity in the Nazi atrocities, what might be the standard for reflection that would allows us to distinguish some ways of opening out the past as 
morally superior to others? Gross's critical intervention in the unfolding debate over the interactive nature of museum as praxis seems guided by the hope that some better future will grow out of a better understood past. But, then, how does a didactic of destabilization go together with the kind of informed decisionmaking associated with more responsible forms of public policy? In other words, what are the implicit criteria (universal, procedural, or pragmatist?) for gauging the "true balance between remembering and forgetting"??

\section{Managing the Future}

Gross's critiques are structured around a certain ambivalence, as they oscillate between favoring exhibits primarily aimed at provocation, on the one hand, and favoring exhibits aimed at moral guidance within political debate, on the other. This tension between provocation and guidance is grounded in his traditional understanding of the museum exhibit - the assembly of artifacts, images, and texts -- as a "text" broadly conceived, namely, as an arrangement of material objects (including, but not limited to verbal items) whose deliberate composition is meant to convey certain moral messages or evaluative judgments that the viewer is supposed to "read off" the exhibit as a whole. 3 That is to say, his treatment of museum exhibits as a form of public address creates an internal tension in the process of "creat[ing] public memory publicly." It seems that Gross wants meaning-formation in the public sphere to be open-ended, but not too open-ended.

By foregrounding the role of the visitors as constitutive part of any museum experience, Gross radically opens up historical exhibits as rhetorical texts, and in doing so he complicates the notion of the museums' textuality. As a "diffuse" text, a historical

${ }^{2}$ Here Gross's formulations tend to gloss the normative standards for judging when such balance is achieved. While his previously mentioned nod to John Dewey in the essay on Enola Gay exhibit remains suggestive, it is worth noting that Dewey's pragmatist approach, too, has been questioned regarding the political import and feasibility of his theoretical considerations. As astute commentators like Giles Gunn have argued. Dewey may well be able to answer this criticism about unspecified normative standards needed for public policy making, and so may Gross. But then, these criteria ought to be made explicit (Gunn, 2013).

3 For one of the most frequent references among cultural theorists, rhetoricians, and social critics for this understanding of material arrangements as a "text" intended for a public audience. Barthes comments on "material which as already been worked on so as to make it suitable for communication" (Barthes, 1972, $110 \mathrm{ff}$., italics in the original). 
exhibit becomes fluid and flexible, subject to restructuring and dependent on the social interconnectivity the viewers bring to the site in making sense of their contemporary lives and their historicity (Brummett 1994.) Here his insistence on "creation of public spaces hospitable to both [competing viewpoints on history] and, equally, to their critique" clearly shows that Gross does not wish to prescribe what the visitors ought to think or learn, for example, about the atomic bomb in Hiroshima. However, the underlying vision of social progress instills a kind of moral chronology, that (re)stabilizes the textuality of museum exhibits. That is to say, the more directly museums are put in the service of fostering moral progress for learning the mistakes of the past and not repeating the failure in proper learning from the history, the more pressure is generated to integrate contesting views about past atrocities. In this regard, treating a museum exhibit as a conduit for "selective narrativization" tends to restore stability within its textuality. Such view of the role of museums implies a sense of coherence by way of giving more control to the curators, who are expected to ensure that the exhibit under consideration does not generate too many rival interpretations / perspectives, which would put the agenda of fostering moral maturation at risk. As a case in point, Gross criticizes the curators at the Smithsonian Institute for underplaying their role as public educators (Gross, 2002, 476.) He criticizes them for their "failure of concern" about the "opinions of potential visitors as a part of the planning process," for having "no more than a gesture of the evaluation of exhibition as a vehicle of democratic public education, and neglect[ing] [...] the actual behavior of museum visitors" (Gross, 2002, 484).

This criticism of failed adaptation to a prospective audience seems to suggest that the communicative transaction at stake here is an intricate dynamics of careful encoding apt to provoke diverse decoding. While Gross's diction leaves some room for varied interpretation, he seems to endorse diversity more on the side of the recipients (i.e. the exhibit-viewers) than on the side of the organizers (i.e. the museum curators). In this regard, Gross seems to construe museum exhibits as a form of public address. The museum-goers are "provoked" into multiple responses, yet the range of these diverse reactions seems to be inscribed, ahead of time, within certain moral limits set by the implicit story line laid out by the curators. It seems, then, that Gross assigns to curators the role of public intellectuals "behind the scenes," who are delivering a moral message encoded in the exhibit at hand - a message that is not monolithic or dogmatic, yet clearly limited in its moral compass. The provocative dynamics of museums is therefore 
off-set by his insistence on responsible "narrativization" in the service of fostering democratic culture. In this sense, the imperative of historical learning (i.e., the obligation to learn from history) Gross embraces turns out to be narrower than initially apparent.

Furthermore, as Peter Thompson explains, narratives often aim to downplay the contingency factor in history, and give us a sense of control and manageability. He discusses how our future visions (of a better society, etc.) are so many attempts to control history and stabilize our moral universe, as we keep trying to bleach any hint at unpredictability from our moral identities. As Thompson puts it:

We force ourselves to impose the pattern which emerged out of contingency onto the future and believe that we have discovered a means of predicting and thus creating it on the basis of our retrospective teleology. We then call that model utopia (in the programmatic sense) when it actually just reifies a coincidence of past and current events into a dogmatically determined future in which what was process becomes program and is then projected forward in necessitarian fashion (Thompson and Zizek, 2013, 97).

If we apply Thompson's remarks to Gross's discussion, destabilizing our historical self-understanding is guided by tacit assumptions as to how the viewer's moral values should be challenged and restructured. For instance, forgetting does not seem to be an option for Gross. As he criticizes the aforementioned Vienna 1938 exhibit's failure to generate public debates, a nonresponse is seen as a sign of complicity with the stability of existing knowledge and values (e.g. national ideology. The exhibit thereby risks a form of "commemorat[ing] in advance," that is, presentating past about "historical guilt" seem to be foregone conclusions to the point where the viewers no longer feel the need to actively deliberate about the meaning of historical events, such as the Holocaust and Hiroshima (Nora, cited in Gross, 2002, 467). Such neglect in historical learning will fail to "make [the] connection between us and the dead" and lead to forgetfulness about the lessons from past atrocities (Gross, 2002, 469).

This prevention by (re)cognition approach toward remembrance places a high degree of confidence in our ability to manage memory, i.e., to anticipate and control the moral response patterns by museum visitors to the respective exhibit. Mario Di Paolantonio argues that the relation between learning and forgetting is not one of simple contrast, such that historical self-transparency can directly be correlated with pedagogical success. Instead, we should 
become more sensitive and open to the "possibility of learning from memory's failures and lapses rather [sic] through prescriptions of how memory should be utilized" (Di Paolantonio, 2010). Emphasizing forgetting helps us question the extent to which the requirement that we get full clarity about our moral origins in order to take responsible action now (for a better future) may be misguided.

\section{Museum As Epic Theatre}

If we continue seeing museums as a site of historical learning, as Gross passionately advocates, how might we re-envision the experience of "learning" to negotiate the perceived tension in Gross's account? Bertolt Brecht's idea of "epic theatre," I propose, offers a novel way for us to elaborate on the critical language of destabilization and stabilization offered by Gross. Terry Eagleton succinctly captures the nature of the "epic theatre" as follows:

The task of theatre is not to 'reflect' a fixed reality, but to demonstrate how character and action are historically produced, and so how they could have been, and still can be, different. The play itself, therefore, become a model of that process of production; it is less a reflection of, than a reflection on, social reality. Instead of appearing as a seamless whole, which suggests that its entire action is inexorably determined from the outset the play presents itself as discontinuous, open-ended, internally contradictory, encouraging in the audience a 'complex seeing' which is alert to several conflicting possibilities a any particular point (Eagleton, 1989, 60).

As a venue for unsettling a society's customary self-perceptions (including its unspoken taboos, "open secrets" about stigmatized groups, codes of honor, and ranking of values - e.g. personal independence over social security), the task of "epic theatre" is to shake the political out of the apolitical, as it were. Such theatrical experimentation seeks to create an atmosphere of (uncomfortable) surprise effects, in which we may detect political tendencies in seemingly apolitical contexts or behaviors.

This idea of "epic theatre" shifts our primary critical emphasis on stabilizing moral vision back onto the side of destabilizing moral sensibilities. From this perspective, we can see the items on display in museums as functioning like the actors' "out-of-character" performances on stage in Brecht's "epic theatre." This approach allows us to take a step toward re-envisioning historical pedagogy in terms of creative experimentation rather than responsible 
decoding. Such theater-based analysis puts a different spin on the notion of "managing memory," in that the role of the exhibit-viewer moves from reader to co-producer of meaning. I will briefly explore this possibility of learning through experimentation by looking at the recently opened exhibit entitled "Complicity and Collaboration" at the United States Holocaust Memorial Museum in Washington D.C.

At first glance, "Complicity and Collaboration" differs greatly from the USHMM's permanent exhibit as it does from numerous traditional historical exhibits. Rather than telling a story through a selection of images, artifacts, and descriptive texts, this exhibit is an assembly of questions that accompany visual scenes from Germany and the occupied territories under Nazism. For instance, there is a seemingly mundane photograph showing a crowd of women. From a panel beside it, one learns that this scene belongs to an auction, where furniture and other belongings confiscated from Jewish homes are sold. Such confiscations happened openly, and the buyers knew where these materials came. The exhibit asks the viewer whether these people are complicit in the reigning Nazi ideology and its ultimate direction toward the Holocaust.

What is more, the exhibit itself does not provide or anticipate answers to any of these questions nor does it try to stir one's judgment into one direction or the other. Wondering about one's own hypothetical role in such a scheme, and thus moving from one scene to the next, it is quite difficult for the spectator to develop a stable judgment or confidence in his/her moral discernment. Provisional answers that might have been formed vis-à-vis the aforementioned auction photograph may undergo sudden change upon encountering the image of a 15-year old German girl by the public swimming pool, with the sign "No Jews." In its unchartedjourney character, the exhibit provides us a space where we are urged to experiment with our own moral convictions from multiple perspectives, without foregone conclusion about the degree to which these perspectives can be integrated. The scenes on display can be mobilized in ways that will make us apprehensive about scenes from our everyday life-world (at swimming pools, hair salons, coffee houses, libraries, grocery stores, etc.) that we never thought could be worrisome or morally weighty at all. Museumvisitors qua participants in experimental memorialization might leave the exhibit with a cacophony of moral voices in their head.

In such an epic-theatrical setting, each encounter with a "scene from the past" may activate or amplify desires, aversions or other emotional capacities we didn't know we had or needed. Through a nearly kaleidoscopic experience, the viewers are compelled to co- 
produce the entire exhibit's meaning as if they were confronted with a mosaic that is not only unfinished, but whose parts keep shifting along with the viewers' own movement as they make their way past the different items on display. ${ }^{4}$ Historical contingencies are incorporated into an open-ended museum experience with the capacity to enrich our participatory activity as co-producers of remembrance; and such enrichment does not entail any teleological guarantee for social progress or moral maturation. Instead, historical learning refers to a risky process of loosening and exposing morally charged background assumptions we had tacitly registered. The workings of museum as epic theatre dissociates curators from their role of moral teachers and opens up the museum encounter as a creative space similar to what Di Paolantonio calls "an anachrony in our present." (Di Paolantonio, $2010,8)$. Instead of ordering our historical data in a linear fashion (positing these scenes as a "past" distant from the present), the exhibit encourages us to creatively, if uneasily, mix them up by interspersing scenes from the past with scenes from the present and/or with an imagined future. Thus Brecht's notion of epic theatre makes visible the historical vicissitudes of our individual lives, in ways that shock us out of experiential complacency, but also give us time to experiment with our moral profile(s) in the face of intersecting scenes. The newly emerging relations that arise out of the experimental museum experience can no longer clearly be classified as "past" or "present." Instead, these experiences emerge as "anachronistic-in-the-present," in that they are geared to detect political tendencies in presumably apolitical settings.

\section{Conclusion}

Understanding the museum as epic theatre is not meant to expose our covert "micro-fascism," to borrow the phrase familiar from Deleuze and Guattari (Deleuze and Guattari, 1997, 214). The latter claim to exposure would re-raise the question about the independent normative basis of the moral platform from which this general accusation is made. Instead, memorialization modeled on epic theatre is animated by a continued effort to scrutinize certain

4 In this regard, my present account of museum as epic theater can be read as moving the experience of museums closer to the experience of memorials such as Blair et.al.'s work on the Vietnam Memorial in Washington D.C., and James E. Young's "counter-monuments." While the distinction between memorial and museum must not hastily be conflated, there is an affinity between the kind of critical experience that museums and memorials can generate, respectively. See Carole Blair, Marsha S. Jepperson, and Enrico Pucci, 1991; Young, 1993. 
phenomena from a given cultural environment to notice disturbing trends where we expect them the least. The immediate challenge is not to assess starkly immoral data by using our moral radar, but to change the receptive registers of that radar itself. In this sense, museum as epic theatre promotes "[a]n unpredictable and noncompliant approach to remembrance and learning in the museum" (Di Paolantonio, 2010, 2).

Thus Uwe Steiner remarks, "By questioning the conventional character of the theatre as entertainment, the epic theater invalidates traditional aesthetic standards and at the same time threatens the privileged position of professional critics" (Steiner, 2010,104 .) In the same way, by questioning the conventional approach to museum exhibits as moral education, the notion of epic theatre dramatizes the possibility that seeing museums as material sites of public address undermines the museums' potential to revise our moral self-perceptions and facilitate historical learning. Alternately, the participatory nature of epic theatre points to a new understanding of the museum as an interactive laboratory for reshaping social experience by acknowledging and incorporating contingencies, according to an understanding of historical temporality that is as skewed as it is creative. From this point of view, the primary challenge of ethical guidance does not so much consist in rectifying our perspective on an "obviously immoral" past that we must not repeat, but on realizing how seemingly non-moral aspects of our everyday life may direct us toward an immoral future that is still in the making. In keeping with those passages where Gross emphasizes the need for destabilizing the interpretive frames in which we habitually organize our ethical experience (as opposed to those segments where he seems to opt for a pre-conceived integration of moral perspective by the curators for the audience), museums need not be sites where moral standards or convictions are confirmed or instilled. Rather, they are sites where moral (self-) perceptions are "unlearned" or loosened for the sake of social change. Thus, reimagining museum as epic theatre allows us to evaluate its capacity to destabilize our moral sensibilities in terms of enriching, rather than instructing, our future visions.

\section{Reference List}

Barthes, R. Mythologies. Annette Lavers (Trans.) New York: Hill and Wang, 1972.

Bennett, T. The Birth of Museum: History, Theory, Politics. New York: Routledge, 1995

Blair, C., M. Jepperson, and E Pucci. "Public Memorializing in 
Postmodernity: The Vietnam Veterans Memorial as

Prototype." Quarterly Journal of Speech 77: (1991): 263-288.

Brummett, B. Rhetoric in Popular Culture. New York: St. Martin's Press, 1994

Deleuze, G. and F. Guattari. A Thousand Plateaus: Capitalism and Schizophrenia. Minneapolis: University of Minnesota Press. 1987.

Dickinson, G, B. Ott and E. Aoki. "Spaces of Remembering and Forgetting: The Reverent Eye/I at the Plains Indian Museum," Communication and Critical/Cultural Studies 3 (2006): 29.

Di Paolantonio, M. "Beyond the Rhetoric of 'Never Forget': Considering what a Museum of Forgetting Could be a museum of..." Presentation, Philosophy of Education Society of Great Britain Annual Conference. New College, Oxford, Great Britain. March 26-31, 2010. Available at: https://www.philosophy-ofeducation.org/conferences/Conference details.asp?id=16

Eagleton, T. Marxism and Literacy Criticism. New York: Routledge. 1989.

Gross, A. "When Nations Remember: Hiroshima in the American Consciousness and Conscience." Prospects 27 (2002): 476488.

Gunn, G. (2013) Ideas to Die For: The Cosmopolitan Challenge. London and New York: Routledge, 2013.

Habermas, J. "Walter Benjamin: Consciousness Raising and Rescuing Critique.” In G. Smith (Ed.) (Pp. 90-128.) On Walter Benjamin. Cambridge, MA: MIT Press, 1991.

Lynch, J. "Prepare to Believe: The Creation Museum As Embodied Conversion Narrative." Rhetoric and Public Affairs 16: (2013): 5 .

Miller ,T. and G. Yudice. Cultural Policy. Thousand Oaks, CA: Sage Publications, 2002.

Steiner, U. Walter Benjamin: An Introduction to His Works and Thought Trans. M. Winkler. Chicago: The University of Chicago Press, 2010. 
Thompson, P and S. Zizek. The Privatization of Hope: Ernst Bloch and the Future of Utopia. Durham, NC: Duke University Press, 2013.

Trinh, T. Minh-ha. Woman, Native, Other: Writing Postcoloniality and Feminism. Indianapolis, IN: Indiana University Press, 1989.

Young, J. E. The Texture of Memory. New Haven: Yale, 1993. 